\title{
Diabetes management with practice of Yoga Asanas and 2 spoons of Amla Juice and Turmeric for 90 days
}

\author{
Phaneendra Kumar \\ Tata Consultancy Services, Bengaluru, India
}

\section{KEY WORDS}

Diabetes

Lifestyle

Meditation

Pranayam

${ }^{*}$ Corresponding Author:

Phaneendra Kumar

Tata Consultancy Services,

Bengaluru, India

Contact no: +91-9739961624

E-mail: kumar.phaneendra@gmail.com

\begin{abstract}
This case study is of a Diabetic person who works as an IT software engineer in Bangalore. Yoga Therapy Workshop was organized for 3 weeks (15 working days) in IT Company. The person showed interest in implementing the yoga therapy protocol for a longer duration to control her Diabetes. Her sense of well-being improved within one week of following the protocol which included Asanas, Meditation, Pranayam and Home Remedies such as Amla juice with Turmeric. She practiced yoga regularly and consumed 2 tablespoons of Amla Juice with 1 gram of Turmeric on an empty stomach for 90 consecutive days. She was not on any medication since she was diagnosed as a diabetic. Yoga has shown significant improvement in reversing the patient's diabetes condition and returning her blood sugar levels to normal range.
\end{abstract}

doi: $10.38205 /$ imcr.020122

\section{Introduction}

According to the International Diabetes Federation in 2019 (1), diabetes has a prevalence of 463 million people. 4.2 million deaths can be attributed to diabetes worldwide in the year of 2019. With an additional 374 million people at risk of developing diabetes, Diabetes is also one of the major causes for severe morbidity with complications such as diabetic retinopathy, stroke, coronary artery disease, peripheral vascular disease, diabetic nephropathy and lower limb amputations. With such a burden on society, it is imperative to find therapies to prevent, alleviate and possibly treat diabetes. There has been decrease in the average age of onset of diabetes over the years and now it is being seen more commonly amongst youngsters, both male and female, who predominantly have sedentary jobs, i.e. software companies, etc. Major factors in the development of diabetes include a sedentary lifestyle, chronic stress, an unhealthy diet comprising of high levels of refined carbohydrates and sugars, smoking etc. A key marker for diagnosis of diabetes is HbA1c levels, with a value less than 5.7 indicating a non-diabetic and a value greater than 6.5 indicating diabetes. In this case study an integrative yoga protocol was used in an attempt to improve patient lifestyle as well as reduce key diabetic markers (i.e., HbA1c). This case study demonstrates positive changes in the quality of life as well as in the patients HbA1c levels which lowered to non-diabetic levels by practicing the integrative yoga protocol (Asanas, Pranayama and Meditation) and by consuming Amla Juice mixed with 2 pinches of turmeric for 90 days.

\section{Case presentation}

The patient was a 35-year-old female who was diagnosed with type 2 diabetes mellitus in December 2018 during a routine health check at the age of 34 . She has been working in a $24 \times 7$ shift based (morning, evening and night) sedentary job from 2013 to 2018. Her diet primarily consisted of fast food. She is a known case of Polycystic Ovarian Disease (PCOD) which has caused irregularity in her monthly menstrual cycle. The patient also claims to feel "emotionally weak and depressed"

\section{Recruitment of patient}

Invitation was sent to employees for registering to yoga therapy workshop for 3 weeks (15 working Days). The patient underwent initial 3 weeks ( 5 days/week) of therapy program (70 minutes intervention each day) which was followed for 3 more months (90 days). As per the ethical process, patient written consent was taken. The yoga protocol followed by the patient included warm up sessions, 10-12 rounds of Surya Namaskara, Yoga asanas followed by Yoga nidra and Pranayama.

Also, the patients was advised to consume 2 table spoon of Amla juice with 1 gram of turmeric empty stomach before breakfast. In December 2018, during a routine health checkup the patient was diagnosed with type 2 diabetes mellitus with an HbA1c of $7.2 \%$ and Average Blood Glucose levels of $160 \mathrm{mg} / \mathrm{dL}$ (Figure 1). After 15 weeks of intervention with the above detailed yoga protocol and Amla juice with turmeric, the patient displayed significant reduction in both HbA1c as well as average blood Glucose levels to $5.5 \%$ and $111 \mathrm{mg} / \mathrm{dL}$. 
Table 1: Table showing the Yoga protocol which was performed by the patient

\begin{tabular}{|c|c|}
\hline \multicolumn{2}{|r|}{ Yoga Protocol } \\
\hline Section A & Breathing \& Warm Up Exercises (3-5 Minutes) \\
\hline 1 & Shoulder Exercises \\
\hline 2 & Hand Stretch \\
\hline 3 & Wrist Exercises \\
\hline 4 & Neck Exercises \\
\hline 5 & Back \& Front Bending Breathing \\
\hline 6 & Hip Rotation \\
\hline 7 & Knee Rotation \\
\hline 8 & Ankle Stretch \\
\hline 9 & Ankle Rotation \\
\hline 10 & Complete Body Stretch \\
\hline 11 & Sit Up Breathing \\
\hline 12 & Standing Jog \& Relax by Mukha Douthi \\
\hline Section B & Surya Namaskara (8-10 Minutes) \\
\hline \multicolumn{2}{|c|}{$\begin{array}{l}\text { Initially 4-5 rounds of Surya Namaskara with increment of } \\
2 \text { rounds each day was performed by the patients. }\end{array}$} \\
\hline Section C & Asanas (25 Minutes) 30-45 seconds each Asana \\
\hline 1 & Bhujangasana \\
\hline 2 & Dhanurasana \\
\hline 3 & Shalabhasana \\
\hline 4 & Setu Bandhasana - Bridge Pose \\
\hline 5 & Makarasana \\
\hline 6 & $\begin{array}{l}\text { Leg raising variations (Ardha Halasana - Half } \\
\text { Plough Pose \& Uttanpadasana - Both Leg Rasing) }\end{array}$ \\
\hline 7 & $\begin{array}{l}\text { Jathara Parivartanasana (One Leg Raising and } \\
\text { Twisting) }\end{array}$ \\
\hline 8 & Sarvangasana \\
\hline 9 & Baddha Konasana. (Butterfly Stretch) \\
\hline 10 & Ustrasana \\
\hline 11 & Vajrasana \\
\hline 12 & Parivruta Sukhasana \\
\hline 13 & Vipareeta Bhunamana \\
\hline 14 & Pavanamuktasana \\
\hline 15 & Navasana - Boat Pose \\
\hline 16 & Pashimottanasana \\
\hline 17 & Ardha Padma Paschimottanasana \\
\hline 18 & Janusirsasana - Head to Knee Pose \\
\hline 19 & Parivritta Janu Sirsasana - Revolved Head to Knee \\
\hline 20 & Ardha Matsyendrasana \\
\hline 21 & Malasana \\
\hline 22 & Utkatasana (Half Chair Pose) \\
\hline 23 & Uttanasana - Forward Bending \\
\hline 24 & Trikonasana \\
\hline 25 & Parivrtta Trikonasana \\
\hline
\end{tabular}

\begin{tabular}{|c|l|}
\hline 26 & Tuladandasana - Balancing Stick \\
\hline 27 & Virabhadrasana (All three Variations) \\
\hline 28 & Parivrtta Parshuakonasana - Extended Side Angle \\
\hline 29 & Ardha Chandrasana - Half Moon Pose \\
\hline 30 & Adho Mukha Svanasana - Downward Dog Pose \\
\hline 31 & Vrikshasana \\
\hline 32 & Matsyasana \\
\hline 33 & Upavishta Konasana - Seated Angle Pose \\
\hline 34 & Tiger Stretch \\
\hline 35 & Yoga Nidra \\
\hline Section E & Pranayama (15-20 Minutes) \\
\hline 1 & Kapalabhati \\
\hline 2 & Ujjayi Pranayam \\
\hline 3 & Bhramari - 9 Rounds \\
\hline 4 & Surya Bhedana \\
\hline 5 & Naadi Suddhi - 9 Rounds (Jalandara Bandha) \\
\hline 6 & Nadaanusandana (Akara Ukara MAkara \& OMkara) \\
\hline 7 & Agnisara \\
\hline
\end{tabular}

\begin{tabular}{|l|l|l|}
\hline Test Name & Observed Value & Units \\
\hline HbA1c & 7.2 & $\%$ \\
\hline Average Blood Glucose & 160 & $\mathrm{mg} / \mathrm{dl}$ \\
\hline
\end{tabular}

Fig. 1: Shows the HbA1c and ABG in December 2018 - Pre-Yoga intervention.

\begin{tabular}{|l|l|l|}
\hline Test Name & Observed Value & Units \\
\hline HbA1c & 5.5 & $\%$ \\
\hline Average Blood Glucose & 111 & $\mathrm{mg} / \mathrm{dl}$ \\
\hline
\end{tabular}

Fig. 2: Shows the HbA1c and ABG in August 2019 - Post Yoga intervention.

\begin{tabular}{|l|l|l|l|}
\hline \multicolumn{2}{|c|}{ Reference Range HbAlc } & \multicolumn{2}{c|}{ Reference Range ABG } \\
\hline Below-6.0\% & Normal Value & $90-120 \mathrm{mg} / \mathrm{dl}$ & Excellent Control \\
\hline $6.0 \%-7.0 \%$ & Good Control & $121-150 \mathrm{mg} / \mathrm{dl}$ & Good Control \\
\hline $7.0 \%-8.0 \%$ & Fair Control & $151-180 \mathrm{mg} / \mathrm{dl}$ & Average Control \\
\hline $8.0 \%-10.0 \%$ & $\begin{array}{l}\text { Unsatisfactory } \\
\text { Control }\end{array}$ & $181-210 \mathrm{mg} / \mathrm{dl}$ & Action Suggested \\
\hline Above $10 \%$ & Poor Control & $>211 \mathrm{mg} / \mathrm{dl}$ & Panic Value \\
\hline
\end{tabular}

\section{Discussion}

Younger age of onset for type 2 diabetes mellitus is becoming an unfortunate trend over the past 10-20 years. It can largely be attributed to an increase in sedentary lifestyle, increased intake of processed sugars and refined carbohydrates and increased levels of chronic stress. The present study discusses about the case of Young age Diabetes onset in a woman aged 34 years. 
Due to this modern lifestyle, there has been an increase in the incidence a metabolic syndrome and insulin resistance. This not only increases the risk of developing type 2 diabetes mellitus but also other disease states such as dyslipidemias, polycystic ovarian disease, nonalcoholic fatty liver disease, obesity, etc.

The practice of yoga/exercise can help in lowering blood glucose levels by cellular glucose uptake via the insulin independent AMP Kinase pathway in striated muscle cells. This reduces the blood glucose burden and helps in better insulin sensitization (2).

Yoga and meditation have also shown a decrease in stress levels as well as provide better regulation of cortisol levels (3). Cortisol increases blood glucose levels as well as insulin resistance. Chronically elevated cortisol levels can also have an impact on long term glycemic control (4). Shift work with night shifts which alter our circadian rhythm has been shown to increase blood glucose levels. The reduction of stress in the patient after yoga and meditation can be noted by the patient's perception of better well-being.

Amla Juice has been shown to have multiple uses in ayurvedic medicine. It has been shown to have anti-inflammatory properties, anti-oxidant properties, anti-pyretic and immunomodulatory properties to name a few. These properties have been implicated in studies to have improved glycemic control in patients (5).

In a study on diabetic rats, turmeric was shown to decrease blood glucose as well as HbA1c levels (6). This result aligns well with the findings seen in the above patient. Our study has shown that 70 minutes of Yoga practice for a period of 3 month, along with empty stomach intake of Amla juice and turmeric, may be helpful in reversing the insulin sensitivity in condition of Type 2 diabetes mellitus.

The combination of these modalities in the yoga protocol assigned to the patient seem to have re-sensitized the patient to insulin and improved glycemic control drastically, to the point where she has reversed her diagnosis of diabetes.

\section{Limitations}

This case study is based on a single patient and self-declaration on the daily practices for 3 months. However, as a case study, it is hard to conclude whether the parameters measured are due to Yoga practice or consuming Amla Juice for 3 months or any other factors which are not disclosed. A larger randomized study on the effectiveness of Yoga therapy as an integrative approach will have strong base.

\section{Conclusion}

Improved Lifestyle resulted in reduction of stress and better family relationship and bonding. Patient was practicing the Asana, Pranayama and Meditation during morning for 70 minutes.

\section{Future implications}

The present case study gives an insight about the efficacy of Yoga in replenishing insulin sensitivity and potential of Yoga in prevention and management of type 2 diabetes mellitus.

\section{Acknowledgements}

Author acknowledges the efforts of the diabetic for compiling the data and become available for participation, discussion, and writing of the manuscript. Author is also thankful to Aniket Kolee - Head of TCS Data Office \& Global Head of Yoga Council and Sunil Deshpande - TCS Bangalore Center Head from Tata Consultancy Services for providing necessary support towards welfare of the employees and conducting Yoga Therapy Workshop. Also, thanks to ES Chakravarthy - TCS Global Head RMG.

\section{Author contributions}

Author has accepted responsibility for the entire content of this submitted manuscript and approved submission.

\section{Informed consent}

Yes.

\section{Source of funding}

None.

\section{Conflict of interest}

None.

Received Date: 21-07-20; Revised Date: 03-01-21

Accepted Date: 04-01-21

\section{References}

1. Diabetes facts \& figures, The International Diabetes Federation, https:// www.idf.org/aboutdiabetes/what-is-diabetes/facts-figures.html

2. Viollet B, Lantier L, Devin-Leclerc J, et al. Targeting the AMPK pathway for the treatment of Type 2 diabetes. Front Biosci (Landmark Ed). 2009;14:3380-3400. Published 2009 Jan 1. doi:10.2741/3460

3. Kamei, Tsutomu, et al. "Decrease in serum cortisol during yoga exercise is correlated with alpha wave activation." Perceptual and motor skills 90.3;(2000):1027-1032.

4. EV Van Cauter, KS Polonsky, JD Blackman, D Roland, J Sturis, MM Byrne, AJ Scheen, Abnormal temporal patterns of glucose tolerance in obesity: relationship to sleep-related growth hormone secretion and circadian cortisol rhythmicity, The Journal of Clinical Endocrinology \& Metabolism, Volume 79, Issue 6, 1 December 1994, Pages 1797-1805.

5. Dasaroju, Swetha, and Krishna Mohan Gottumukkala. "Current trends in the research of Emblica officinalis (Amla): A pharmacological perspective." Int J Pharm Sci Rev Res 24.2;(2014):150-59.

6. Arun, N., Nalini, N. Efficacy of turmeric on blood sugar and polyol pathway in diabetic albino rats. Plant Foods Hum Nutr 57;(2002):41-52. 